\title{
"Pack 'em, rack 'em and stack 'em": The Appropriateness of the Use and Reuse of Shipping Containers for Prison Accommodation
}

Elizabeth Grant, (The University of Adelaide, Australia)

\begin{abstract}
Shipping containers are gaining increasing recognition for their apparent durability, adaptability, light weight, 'low cost' and ease of stacking, spurring a trend that has resulted in shipping container sculpture, homes, housing, hotels, and museums. The use of prefabricated, pre-manufactured and prototype building methods for prison construction has grown considerably as some jurisdictions attempt to deal with the construction of prisons with speed and economy. In the last three years, shipping containers have been used in the prison sector as a way of managing burgeoning prison populations. Recent prison developments in both Australia and New Zealand where shipping containers have been employed for prisoner housing are of considerable interest. In this article, the financial, functional, structural, technical, environmental and architectonic impacts of this approach are discussed.
\end{abstract}

Keywords: Prison construction, Shipping containers, Prison architecture, Material reuse, Building methods

\section{Introduction}

The advent of the shipping container revolutionised the transport industry (Levinson 2006) profoundly impacting the geography of production and distribution. Production became globalised as distribution systems were able to interact more efficiently (Theo and JeanPaul; 2008; Notteboom and Rodrigue 2008) with the invention of the shipping container, which allowed goods to be moved between rail, road and sea transport with minimal handling. In 1970, container design was standardised worldwide through the introduction of the International Standards Organization (ISO) shipping container (Sawyers 2011). A typical ISO compliant container is constructed of corrugated weathering and corrosion resistant steel with double leaf doors at one end. The walls are built using a frame and filling design that allows for size and load bearing reinforcement. Both frames and fillings are designed to withstand dynamic and static loads.

The International Standards Organisation stipulates the standards for the dimensions, waterproofness, strength, handling and methods to secure shipping containers (Smith 2005). While there are some minor variations, containers generally measure 2.44 m wide by $2.44 \mathrm{~m}$ high, and either $6.1 \mathrm{~m}$ or $12.19 \mathrm{~m}$ long. Containers must be able to be stacked up to seven units high (Smith 2005). To conform to the standards, the eight corners of containers must have castings with openings for 'twistlock' fasteners. Containers fall into two categories depending on their use. When used solely for shipping, containers are generally referred to as an ISO container, a cargo container, or a 'Conex Box'. When used for building construction or storage, containers are referred to as an ISBU (Intermodal Steel Building Unit) Module or a 'GreenCube'.

When used for transport purposes and exposed to harsh sea conditions and handling, shipping containers have an average life span of between 10 and 15 years (Spurgeon et al. 2003). Some containers are lost at sea while others are written off in handling accidents (Muller 1999; Informa Group 2012). Around one million containers leave the transport sector 
annually with old, broken, obsolete, damaged or corroded boxes being scrapped and stockpiling as ubiquitous artefacts of industrial capitalism (Kalkin \& McLean 2008). However, approximately 300,000 to 500,000 containers experience an afterlife (Spurgeon et al. 2003). These containers go to new industries that have arisen to sell or lease containers or modify them for other uses. One such industry is the modification of shipping containers for building purposes.

Initially modules were favoured for use in post disaster scenarios and in military and mining operations. Their value lay in the capacity of the units be easily transported and rapidly redeployed. In the last decade, there has been growth in the use of shipping containers in other contexts and they have been employed for a myriad of uses. Containers serve as sleep-outs, garden sheds, workshops, student and disaster housing, artists' studios, storage facilities, sales, site and ticket offices, lunch rooms, cafes, and ablutions blocks. A British country house used refrigerated containers to kill insects infesting antique carpets (CS Shipping Containers 2012). The Masakhane Container Mall was built from converted shipping containers in a black settlement in South Africa when there were inadequate funds to build a permanent mall (Keller 1993; Spurgeon et al. 2003). London's Container City (Chapa 2007; Urban Space Management Ltd 2012) and the University of Utrecht Student Housing (Brandt 2011) are interesting examples of large-scale cargo container complexes. Container City is bright and colourful and relies on component pieces rather than units to create adaptable liveable spaces (Chapa 2007) while the Utrecht student housing complex took a one container per unit approach (Brandt 2011). The growth of industries for container conversion has been phenomenal. There are many businesses solely focusing on adapting various grades of pre-used containers for use in the built environment. Other firms are also fabricating new containers for immediate use as accommodation.

A number of countries have also used shipping containers as 'quick fix' solutions for prison accommodation. In 1999, the Western Australian Government purchased 24 renovated containers to use as temporary prison cells to help alleviate overcrowding at the then Canning Vale (now Hakea) Prison. The twenty four renovated shipping containers were fitted out with a window, shelves, floor coverings and a television (Le Grand 1999) but had a relatively short life span. Reports cited that the containers "corroded [and] design problems created security risks" (Winter 2011). In 2002, the US Government adapted shipping containers for use as cells for holding foreign nationals at Camp Delta at the U.S. Naval Base, Guantánamo Bay. Camp Delta was a detention facility with the capacity to apparently hold 612 prisoners in separate units. Each unit was reportedly constructed of "...shipping containers cut halfway lengthwise with the pieces stuck together end to end. Cells were small, six foot eight inches by eight foot with steel beds fixed to the steel mesh walls" (Tucker et al. 2010 p. 502). The units are reported to measure $2.43 \mathrm{~m}$ long, $2.07 \mathrm{~m}$ wide and $2.43 \mathrm{~m}$ tall and constructed with metal mesh material on the sides (Global Security 2011). Canover in 2003 described the layout of Camp Delta as consisting of "twenty-four ...cells, constructed out of Connex shipping containers placed end to end, situated opposite 24 others, and a roof with ventilators is constructed overhead; this assemblage of 48 cells constitutes a cellblock. So far, there are 19 of these cellblocks at Camp Delta, suggesting a capacity of approximately 1,000" (Conover 2003).

The conditions and practices at Guantánamo Bay have always been a point of contention and in 2004, it was reported that Pentagon planners were seeking funding to build a purpose built prison to replace the rows of rugged cells fashioned from shipping containers transported from South Asia (Kenny 2003; Rosenberg 2004). In his second day in office, President Obama issued a directive to cease detentions at Guantánamo Bay (Mendelson and CSIS Working Group on Guantánamo and Detention Policy 2008) and close the facility (Crook 2009). Due to the refusal of the US Senate to release funding for the phasing out of the Guantánamo Bay Facility, a prohibition of the use of federal funding to "release, transfer or incarcerate detainees detained at Guantanamo, Cuba to or within the United States"

Grant E (2013) “Pack 'em, rack 'em and stack 'em": The appropriateness of the use and reuse of shipping containers for prison accommodation', Australasian Journal of Construction Economics and Building, 13 (2) 35-44 
(Corcoran 2011 p. 209) and the subsequent passing of Government bill banning the transfer of detainees to the United States (even for prosecution), operations at this point continue at the facility (Corcoran 2011).

More recently, shipping containers have been employed for prison construction in both New Zealand and Australia. With a paucity of research into the use and reuse of shipping containers for this specific use, it is a timely and important to consider the benefits and constraints of reusing shipping containers from a number of perspectives. This article will describe recent projects, discussing the cost effectiveness, building performance and the environmental and wider implications of taking this approach.

\section{The Rimutaka Container Prison Project}

The Rimutaka Container Prison Project was conceived to increase the capacity of an existing prison to cope with a burgeoning prison population. New Zealand's prison population peaked in 2010 at 8,816 people and forecasts suggest the prison population is expected to reach 10,314 by 2017 (Department of Corrections New Zealand 2010). With projections of an increasing prison population, New Zealand Corrections commenced investigating options to increase prison capacity. One initiative included the use of prefabricated or modular prison cells as a way of housing rising prisoner numbers.

The additional unit developed at Rimutaka Prison was designed to house 60 low to medium security prisoners using ex-shipping containers. The design of the unit followed the design principles used in many of New Zealand male prisons, where cells and ablution blocks are located around three sides of an open court yard. The entrance administration, staff facilities, control room and dining spaces are accommodated on the fourth side (Grant 2009; Department of Corrections 2012). This design of individual cells located around an external area has some disadvantages. The central external area is unusable during inclement winter and staff tend to have less interaction with prisoners. Most modern prisons in both Australia and New Zealand situate cells around a central internal living area (using the principles of third generation or podular design) to increase staff interaction with prisoners. The shipping containers are covered by a roof that encompasses the complex. In all, 23 high grade shipping containers were used to develop the unit and prisoners are accommodated in a mix of double and single bunked cells with each shipping container housing three cells (Department of Corrections New Zealand 2009).

The budget for the Rimutaka Prison Container Project was set at \$5.4m (NZ) (\$4.46m AUD) for infrastructure and services, plus a further \$2m (NZ) (\$1.65 AUD) for fencing and external security elements. While it is reported the project was completed under budget (Rawlinsons 2010), estimates of the actual cost of the refit of the containers and development vary slightly. One source suggests the capital cost of each bed lies somewhere between $\$ 53,000$ NZ (Wheeland 2010) (\$43798 AUD) and \$70,000 NZ (Gower 2010) (\$57846 AUD). The Rimutaka Prison Container Project immediately spurred interest by other correctional jurisdictions also examining cost-effective methods to house burgeoning prison populations.

\section{The South Australian Developments}

One such jurisdiction was the South Australian Department of Corrections. After the cancellation of the South Australian Prison Project in 2009 (where a major facility was to be built to replace ageing prison stock) the Department of Corrections needed to look at methods to increase beds at existing prisons. Given the apparent success of the Rimutaka Prison Container Project, the South Australian Government trialled shipping containers for the provision of additional low security prison accommodation at Cadell Training Centre (Wills 2011). The existing prisoner housing at Cadell Training Centre consists of two types. Some of the low security male prisoners live in standalone cottages in groups of four or five, each with their own bedroom and shared kitchen and bathroom facilities. Cadell Training 
Centre also accommodates prisoners in one cell block (Grant 2008). The new shipping container accommodation followed a cellblock design and was constructed using new prefabricated standard 40 foot containers for the accommodation and association area, with a slightly wider container used as the hallway module. Each container houses six single cells installed with windows and doors, insulation, heating, plumbing, internal walls, roof and external decking and fitted with prison grade fittings (including high grade windows and doors) (Department of Correctional Services, SA 2011).

Shortly after the trial, the South Australian Government Minister announced that "using shipping containers in the construction of new prison cells [meant] the Government [could] deploy new prison cells to cope with any increase in demand in up to half the time with a cost saving of up to 40 per cent compared to traditional cellblock construction," and "construction time [was] only six months, as opposed to more traditional cell construction which could take more than 12 months" (Department of Correctional Services, SA 2011). The Department indicated that "due to the high security features of the modular, it is hard to make a precise cost comparison when compared to recent traditional builds, however the cost for one modular cell is about $\$ 75,000$ (AUD) compared to the cost of a traditional build for a low security unit which ranges from $\$ 100,000$ to $\$ 200,000$ " (Department of Correctional Services, SA 2011).

After the initial trial at Cadell Training Centre, the South Australian Government announced plans to use shipping containers to increase the capacity of an existing prison in Mount Gambier in the south east of the state by more than 100 prisoners in a \$23m (AUD) development (Wills 2011). The new unit was planned to accommodate low to medium security prisoners and constructed as a single storey facility. The design consists of two wings of 54 beds in various configurations ${ }^{1}$ with a central officer's station. Each wing is reported to be designed around a central external exercise yard and reports note that the unit is to be fully self-contained with ablutions, dining and recreation facilities as well as interview and programs rooms (Department of Correctional Services, SA 2012).

Given this low to medium security development is well outside the existing experience of the use of shipping containers in correctional settings, it appears prudent and timely to examine the benefits and constraints to using shipping containers as prison accommodation.

\section{The Benefits of the Use and Reuse of Shipping Containers in Prison Settings}

The use and reuse of shipping containers can be conceived as prefabrication, something that has been used in various formats for prison construction since the 1960s. In particular, precast concrete modules and prefabricated buildings have been increasingly used to construct prisons in Australia and internationally. Various authors have identified the benefits of using prefabricated construction methods for prison construction. In particular, time, cost, quality and productivity benefits through minimisation of on-site operations and duration, less congestion on site, improved health and safety along with greater and more predictable quality and potential greater adherence to budget may be identified as benefits. The shipping container construction model, however, does entail higher materials procurement costs and different on-site skill and equipment needs, but may reduce labour risks and associated costs. It may also improve quality consistency since modules are fabricated in a controlled environment.

\section{The Constraints of the Reuse of Shipping Containers for Prison Construction}

While there may be arguments for the reuse and refurbishment of shipping containers in areas where building materials are scarce, in most urban and rural areas, refurbishment

\footnotetext{
${ }^{1}$ The configurations of planned accommodation include 42 bunked cells, four dual cells (two beds on the floor per cell) and four quad cells (four beds on the floor per cell) with 16 beds for disabled prisoners (Department of Correctional Services South Australia 2011).
}

Grant E (2013) “Pack 'em, rack 'em and stack 'em": The appropriateness of the use and reuse of shipping containers for prison accommodation', Australasian Journal of Construction Economics and Building, 13 (2) 35-44 
costs and logistics of transporting containers will not offset the environmental and economic benefits of using local materials and labour and developing a purpose designed building. This is particularly relevant in prison design where architecture has a profound effect on the experiences of people using the complex and the security and operation of the prison.

As previously mentioned, most Australian and many New Zealand medium and maximum security prisons are designed using the principles of unit management and third generation prison design, where cells are located around a shared interactive internal space. The salient architectural and operational innovations to accompany unit management and third generation design include normalising the environment with soft furnishings, dispersing the dining and recreation activities to the living units and fitting cells with showers and toilets to lessen the prisoner violence associated with shared amenities (Grant \& Jewkes 2013). Prisons are thus designed to promote high levels of interaction between staff and prisoners and spaces are configured so prisoners live within semi-autonomous groups to maximise each individual prisoner's responsibility. Research has shown that prisons designed under the principles of unit management and third generation (or podular) design have decreased numbers of disturbances and assaults.

Shipping containers are most suitable for layouts of small rooms joined together. This layout conforms to the design model that New Zealand has developed where cells open directly onto a central secured courtyard. The modularity does not necessary fit into principles of unit management or third generation design principles. The constraints of using modular units in a design generally result in linear design which has been shown as a factor contributing to increased violence in prison settings. Linear design, in conjunction with the indirect or intermittent staff supervision that must accompany this planning model increases opportunities for both prisoner to prisoner and prisoner to staff violence (Wright \& Goodstein 1991). From this perspective, the use of shipping containers in prison architecture limits the design and may be a barrier to innovative and safe design.

There are also questions about the usability of the central courtyard space in certain climates. While having a central court yard as an association and activity space for prisoners may be appropriate in Mediterranean climates, it is unlikely to be useable in other climates. The site planned for the new project in Mount Gambier experiences cool to cold winters with high average rainfalls with summer temperatures reaching over $40^{\circ} \mathrm{C}$ on certain days. It is likely there will be periods where the central courtyard will be unusable due to wet weather and at other times where due to the extreme heat where it is unsafe for prisoners to be in the courtyard (Grant et al. 2012). There is a capacity for prisoners to be effectively isolated and spend much of their time in individual cells rather than living and socialising as a group.

\section{Building Performance}

There are many factors which may indicate that shipping containers are not suitable from a building performance perspective. Shipping containers are prone to interstitial ${ }^{2}$ and surface condensation $^{3}$ due to the resistive nature of the materials which tend to act as a vapour

\footnotetext{
${ }^{2}$ Interstitial condensation is a form of structural damping that occurs when warm, moist air (generally, from inside a building) penetrates into a wall, roof or floor and meets a cold surface. The air cools, lowering its capacity to carry moisture, resulting in surface condensation. Over time, this condensation may cause rotting of timber or corrosion of metal components. Resulting structural damage may occur without visible indications. This becomes a particular issue if the diffusion of the water vapour through the material is toward the cold side of the structure and if the insulation or thermal conductivity induces a significant temperature difference between the warm and cold sides, such as with heavy insulation or in air conditioned buildings.

${ }^{3}$ Surface condensation is the process by which a gas or vapour changes into a liquid and accumulates on the surface of a material. If the temperature of an object (e.g. metal, glass) falls below what is known as the 'dew point' temperature for a given relative humidity of the surrounding air, water vapour from the atmosphere condenses into water droplets on its surface. The 'dew point' varies according to the amount of water in the atmosphere (known as humidity). Even in cold conditions condensation occurs despite relatively low humidity.
}

Grant E (2013) “Pack 'em, rack 'em and stack 'em": The appropriateness of the use and reuse of shipping containers for prison accommodation', Australasian Journal of Construction Economics and Building, 13 (2) 35-44 
barrier. Condensation will tend to have a detrimental effect on insulation and over time may cause break downs of installed insulation. Vapour barriers need to be used internally and adequate ventilation needs to be installed to alleviate interstitial condensation problems (Smith 2005). There is also a possibility of cold bridging if containers are situated adjacent to each other. Reverberation within the common parts is also a problem and may cause problems due to the sound reflective nature of the external materials and there is a need to consider the installation of a sound absorbent layer or coating to reduce the reverberation. These factors indicate the importance of the installation of insulation, condensation and sound barriers. Shipping containers are generally fitted with an internal frame and insulation. These installations in turn diminish the available floor space, raise the floor and reduce the ceiling heights.

It is also important to consider the structural performance of decommissioned ISO containers for building applications. Containers are decommissioned when they fail to conform to standards which may relate to superficial or structural damage. This damage may compromise the structural integrity or aesthetics of the building. Other areas of structural performance need also to be considered. Strength may also be compromised when the shell is modified, such as by penetrating the container to fit door or window openings. While containers are designed to carry heavy loads, and can support multiples of their own weight, they are not designed to carry loads such as large roofs. In general, containers resist the effects of harsh environments; they are vulnerable to degradation caused by natural elements and need to be rust proofed cyclically. Corrosion does, however, have the potential to have an effect on the structural integrity and the life span of the building.

The cost effectiveness of shipping container projects becomes debatable when refit requirements and additional developments are taken into account. Is it cheaper to design and make purpose built accommodation which fits the correctional operation regimes and needs of prisoners? One must also consider the need for governments to support local building industries. Given that in 2001 China produced 80 per cent of the world's shipping containers and Europe was the second largest producer of containers (Spurgeon 2003), the likelihood of sourcing locally manufactured containers may be difficult in Australia. While the prefabrication of special orders or retrofitting of containers may be able to be completed within the country in question, this takes work away from local building industries and potentially affects the local economy.

\section{The Use and Reuse of Shipping Containers from an Environmental Perspective}

The use and reuse of shipping containers for building projects is often linked to quasienvironmental arguments. Correctional agencies are generally obliged to report on the environmental impact and sustainability of potential projects and are required to reduce environmental impacts wherever possible. The use of shipping containers as building material is environmentally flawed from a number of perspectives. One of the environmental rationales often employed for the use of shipping containers is the apparent reduced levels of embodied energy when compared to other building materials. When new, the embodied energy of shipping containers is high in comparison to other building materials as they are constructed of materials which take large amounts of energy to produce and there are $\mathrm{CO}^{2}$ emissions associated with transport. The level of embodied energy for shipping containers as a building component is thus generally calculated under the assumption that the unit has been pre-used for another purpose (Smith 2005 p. 4). In the most recent prison projects, new prefabricated containers were used (Smith 2005 p. 101). In some instances, arguments have been mounted that the transportation of the shipping container from the place of

Internal surface condensation can occur in areas of high humidity and/or during exceptionally cold weather while external surface condensation occurs in certain climatic conditions with high humidity levels and/or particularly cold weather.

Grant E (2013) “Pack 'em, rack 'em and stack 'em": The appropriateness of the use and reuse of shipping containers for prison accommodation', Australasian Journal of Construction Economics and Building, 13 (2) 35-44 
manufacture to the site amounts to pre-use. This is fallacy - the calculated embodied energy levels of transported new prefabricated units should be calculated without discount.

The environmental performance of shipping container as a building component should be questioned. Extensive insulation is required to make the shells thermally comfortable and avoid corrosion and condensation. Most projects will require air-conditioning or other forms of heating and cooling. The constraints of the modular building system generally do not allow many of the design elements which would be incorporated into 'best practice' passive design to maintain thermal comfort. In turn, the energy consumption of prison accommodation constructed of shipping containers is likely to be high due to the reliance on mechanical heating and cooling.

The transformation of a steel box is an eco-romance where one takes the excesses of capitalism and through human ingenuity transforms them into a serviceable object. Using environmental rationales to justify reusing shipping containers is nonsensical. The environmental waste edict of reduce, reuse and recycle is a hierarchy where emphasis is placed on each action in order to promote ecological balance through conscious behaviour and choices. Unpacking this environmental argument, it becomes apparent that reusing shipping containers does not tackle the excessive global movement of goods that occurs to satiate our consumer society. The reuse of shipping containers simply reduces the evidence of our excessive consumerism and in turn our guilt. Employing human ingenuity to transform the steel boxes can also not be seen as a sustainable or environmental action. Peccei and King (1972) in the landmark publication, 'the Limits to Growth' gave warnings that technology could not function as a way of solving environmental problems. The world's consumption patterns needed to change.

\section{Conclusion}

The global fascination for constructing buildings out of recyclable materials is growing. At first glance, it appears that the shipping containers that litter industrial areas on the outskirts of every major city could be usefully and innovatively recycled to resolve overcrowding issues in prisons. On closer examination, shipping containers are simply not suitable for use as a building component in the prison context. To achieve the level of security and finish required, new containers must be used. In using new containers, environmental advantages of low embodied energy and the use of recycled materials are mitigated and the energy and operating costs are increased.

Prison overcrowding is a very serious issue. It has negative impacts on the prisoner, staff and the functioning of the prison, negating the health and well-being of offenders, undermining human dignity in prisons and rendering the safety and security of offenders and the community vulnerable. Placing more accommodation within existing prisons has been shown to impact prisoners in terms of the availability of programs, staffing levels, drug and alcohol treatment and health care provision, access to services and amenities (Harding 1987 ) and is only one method of tackling overcrowding. Other strategies include reducing the number of prisoners and building new prisons. It is interesting that South Australia have added beds and additional units in the wake of a major prison construction program being cancelled. This stop gap measure is unlikely to address issues within the system. Much of the literature on the topic concurs that overcrowding problems are essentially associated with problems of governance, weak economies and issues in criminal justice systems (Gadon et al. 2006).

One is left to wonder if the use of shipping containers is related to the potential time, cost, quality control and productivity benefits or to other agendas. This becomes particularly poignant in South Australia where the then Treasurer announced that the State Labor Government was happy to "pack 'em, rack 'em and stack 'em'" when cancelling a planned prison project. For many politicians, members of the public and, indeed, some prison staff, 
the provision of amenities in prisons should be "consistent with purposes of discipline and reformation" (Forsythe 2004 p.760). One is left to wonder whether the use of shipping containers for prison expansions is more about political agendas and displaying to the public a punitive attitude to prisons and prisoners alike.

\section{Bibliography}

Brandt, K. (2011) Plugging In: Reinterpreting the Traditional Housing Archetype within a Community using Shipping Containers, (Master of Science Dissertation), The University of North Carolina.

Chapa, J. (2007) 'Prefab Friday: Container City in London', Inhabitat, June

Conover, T. (2003) 'In the Land of Guantánamo', New York Times Magazine, June

Corcoran, E. (2011) 'Obama's Failed Attempt to Close Gitmo: Why Executive Orders Can't Bring About Systemic Change', University of New Hampshire Law Review, 9 (2), 207-235

Crook, J. (2009) 'Contemporary Practice of the United Stated Relating to International Law: General International and U.S. Foreign Relations Law: President Obama Orders Closure of Guantanamo Detention Facilities; Obstacles Remain', American Journal of International Law, 103 (2), 325-331

CS Shipping Containers (2012) Shipping Containers and Container Conversions - 5 Unusual Requests,

www.csshippingcontainers.co.uk/shipping-container-conversions/shipping-containers-andcontainer-conversions-5-unusual-requests Date viewed 1st August, 2012

Department for Correctional Services, South Australia (2011) 'Modular Accommodation Unveiled At Cadell Training Centre', Corrections Newsletter, June

Department of Correctional Services, South Australia (2012) Mount Gambier Prison Expansion, Department for Correctional Services,

www.corrections.sa.gov.au/dcs-projects/mgp-expansion Date viewed: 2nd November 2012

Department of Corrections, New Zealand (2009) Media Release: New container unit to deliver much needed beds,

www.corrections.govt.nz/news-and-publications/media-releases/2010-mediareleases/container cells open for business at rimutaka.html Date viewed: 13th July, 2012

Department of Corrections, New Zealand (2010) Annual Report 2009-10 Wellington, Department of Corrections, Wellington

Department of Corrections, New Zealand (2012) Rimutaka Prison

www.corrections.govt.nz/utility-navigation/find-a-facility-or-

site/find a corrections facility/rimutaka prison.html Date viewed 13th July 2012.

Forsythe, B. (2004) 'Loneliness and Cellular Confinement in English Prisons 1878-1921', British Journal of Criminology, 44 (5), 759-770

Gadon, L. Johnstone, L. et al. (2006) 'Situational variables and institutional violence: a systematic review of the literature', Clinical Psychology Review, 26 (5), 515-534

Global Security (2011) Military Guantanamo Bay - Camp Delta

www.globalsecurity.org/military/facility/guantanamo-bay delta.htm Date viewed: 12th November 2012

Gower, P. (2010) 'A night in shipping container prison', New Zealand News, $2^{\text {nd }}$ June 2010

Grant, E. \& Jewkes, Y. (2013) 'Finally Fit for Purpose: The Evolution of Australian Prison Architecture', The Prison Journal (forthcoming)

Grant, E. Hansen, A. \& Williamson, T. (2012) 'Design issues for prisoner health: Thermal conditions in Australian custodial environments', World Health Design, 5 (3), 80-85 
Grant, E. (2008) Towards safer and more congruent prison environments for male aboriginal prisoners: a South Australian study (PhD Thesis) School of Architecture, Landscape Architecture and Urban Design, The University of Adelaide

Grant, E. (2009) Report on 2008 Churchill Fellowship to investigate correctional facilities for Indigenous prisoners New Zealand, Canada \& Denmark, Churchill Fellowship Trust, Canberra

Harding, R. (1987) 'Prison overcrowding: Correctional policies and political constraints', Australian \& New Zealand Journal of Criminology, 20 (1), 16-32

Informa Group, (2012) Containerisation International Yearbook, Informa Group, London

Joint Task Force Guantánamo and Department of Defense, US Government, (2003) Camp Delta Standard Operating Procedures (SOP) Guantánamo Bay, Department of Defense, US Government, http://www1.umn.edu/humanrts/OathBetrayed/SOP\%201-238.pdf

Date viewed: $12^{\text {th }}$ December 2012

Kalkin, A. \& McLean, W. (2008) Quik build: Adam Kalkin's ABC of Container Architecture, London, Bibliotheque McLean

Keller, B. (1993) 'A South African Mall that Black know-how built', The New York Times, September, 3

Kenny, S. (2003) 'The Hicks Trial' in Conference Proceedings from the National Forum On The War on Terrorism and The Rule Of Law, NSW Parliament House, $10^{\text {th }}$ November 2003

Le Grand, C. (1999) 'Jail Crush Spills to Sea Containers', The Australian, $11^{\text {th }}$ February, 1999, 6

Levinson, M. (2006) The Box: How the shipping container made the world smaller and the world economy bigger Princeton University Press, Princeton

Meadows D \& Club of Rome (1972) The Limits to Growth; a report for the Club of Rome's project on the predicament of mankind Universe Books, New York

Mendelson S \& CSIS Working Group on Guantánamo and Detention Policy (2008) Closing Guantánamo: From Bumper Sticker to Blueprint; A Report of the CSIS Human Rights and Security Initiative and the Working Group on Guantánamo and Detention Policy, Center for Strategic and International Studies, Washington

Muller, G. (1999) Intermodal Freight Transportation, Eno Transportation Foundation Inc., Washington

Notteboom, T. \& Rodrigue, J. (2008) 'Containerisation, Box Logistics and Global Supply Chains: The Integration of Ports and Liner Shipping Networks', Maritime Economics and Logistics 10 (1-2), 152-174

Rawlinsons (2010) Rimutaka Container Prison,

www.rawlinsons.co.nz/our-projects/terrace-downs-high-country-resort-2/) Date viewed: 17th July, 2012

Rosenberg, C. (2004) 'Pentagon plans for long-term detention at Guantánamo', Seattle Times, $10^{\text {th }}$ December 2004

Sawyers, P. (2011) Intermodal Shipping Container Small Steel Buildings, Paul Sawyers, Kentucky

Smith, J. (2005) Shipping Containers as Building Components, University of Brighton, Brighton

Spurgeon, K., Prozzi, J. et al. (2003) The Secret Life of the Container: Evidence from Texas, Transportation Research Board, Texas 
Theo, N. \& Jean-Paul, R. (2008) 'Containerisation, Box Logistics and Global Supply Chains: The Integration of Ports and Liner Shipping Networks', Maritime Economics and Logistics, 10, 152-174

Tucker, S., Roberts, P. \& Zinni A. (2010) The Encyclopaedia of Middle East Wars: the United States in the Persian Gulf, Afghanistan, and Iraq conflicts, ABC-CLIO, Santa Barbara

Urban Space Management Ltd, (2012) Container City www.containercity.com/home.html Date viewed: 1st August, 2012

Wheeland, M. (2010) 'A (Green) Prison Made of Shipping Containers', GreenBiz

Wills, D. (2011) Shipping containers for prisoners at Mt Gambier Prison, AdelaideNow, Adelaide

Winter, C. (2011) 'Union to put cell plan back in its box', ABC News, 4th August 2011

Wright $\mathrm{K}$ and L Goodstein (1991) 'Correctional Environments in Thompson', J. \& Mays, L. (eds), American Jails: Public Policy Issues, Plenum Press, New York, 181-194 